\title{
A Learning Tool to Develop Sustainable Projects
}

\author{
Fermín Sánchez ${ }^{1}$, Jose Cabré ${ }^{1}$, Marc Alier ${ }^{1}$, Eva Vidal ${ }^{2}$, David López ${ }^{1}$, Carme Martín ${ }^{1}$, Jordi García ${ }^{1}$ \\ ${ }^{1}$ Barcelona School of Informatics, ${ }^{2}$ Barcelona School of Telecommunications Engineering \\ Universitat Politècnica de Catalunya, UPC-BarcelonaTech \\ Barcelona, Spain \\ fermin@ac.upc.edu, jose.cabre@upc.edu, ludo@essi.upc.edu,eva.vidal@upc.edu, david@ac.upc.edu, martin@essi.upc.edu, \\ jordig@ac.upc.edu
}

\begin{abstract}
This paper presents a tool we have developed to help engineers to design and develop sustainable projects. The tool has been designed to introduce and evaluate the sustainability of engineering projects in general, but here we present how it can be applied to assess the final project of an engineering degree. This tool is a guide for students to introduce and estimate the sustainability of their projects, but it also helps teachers to assess them. The tool is based on the Socratic Methodology and consists of a matrix where each cell contains several questions that students must consider during the project development and which they must answer in their project report. A positive or negative mark is assigned to every cell, and the sum of all marks states the project sustainability. However, the result is not as simplistic as a final number, but a descriptive sustainability analysis where all questions are answered and every mark justified. A pilot test with some students has obtained good results, but the first Final Degree Project using the proposed methodology will be read in July 2016.
\end{abstract}

Keywords-sustainability; engineering projects; final degree projects;

\section{INTRODUCTION AND MOTIVATION}

In 2010, the Barcelona Schools of Informatics new degree courses got under way by incorporating professional skills, particularly sustainability, into the curricula. The objective was to integrate sustainability into subjects as a natural part of the engineering profession, especially in the so-called Final Degree Project (hereafter FDP). This work was presented in two communications at previous FIE Conferences $[1,2]$.

Nowadays, sustainability skills have already been successfully introduced throughout the subjects on the curriculum and also in the FDP. However, a new problem has arisen: students are asked to present a sustainability analysis of their FDP, but neither students nor teachers are accustomed to drawing up (and evaluating) sustainability analysis.

With a complex, unorganized or unreal method, students will focus on writing a sustainability analysis just to ticket the task as "done", but without a deep reflection (thus, no deep learning) in sustainability. In fact, the first reports presented differed so greatly that the need for a unified criterion about what a sustainability analysis was quickly became clear.

The tool presented in this paper is aimed at assisting students to estimate the sustainability of their projects. The tool also helps teachers to evaluate the project's sustainability. One of the most important objectives of the tool is that it must help students to design a sustainable project rather than just evaluating its sustainability.

The tool consists of a $3 \times 3$ matrix where each cell contains questions that students must answer. The matrix columns correspond to the sustainability dimensions (environmental, economic and social), while the rows correspond to:

- The Project Development (PD), which includes planning and implementation until the moment when the project is deployed.

- The exploitation phase of the project, from deployment to the final dismantling.

- Risks, considered as all variables that may affect the success or failure of the project, but which the designer cannot control.

A mark is assigned to every cell. Marks can be either positive or negative, resulting in a final evaluation rate between -60 and 90 points. The result is not as simplistic as a final number, but rather a descriptive sustainability analysis in which all questions are answered and every mark justified.

We differentiate the concept of FDP, as an academic assignment, from a complete engineering project. Questions directly related to the FDP cover only a part of the matrix, but it is essential for students to evaluate projects as a whole and be aware that, as future engineers, some decisions may have a deep impact on the environment and society.

To our knowledge, this is the first time that a tool of this type has been proposed, and it can be useful for evaluating the sustainability of engineering projects beyond the FDP. The work we present consists of the methodology to introduce and evaluate sustainability in the FDP and the list of questions used to carry it out. Other questions about sustainability that should also be considered in any engineering project are beyond the scope of the present work. The methodology proposed in this paper has been put into practice in a pilot test by several students, who found it quite easy to use. All students of the Bachelor Degree in Informatics Engineering at the Barcelona School of Informatics are currently using this tool to integrate sustainability into their FDP. The first FDP using this methodology will be read in July 2016.

In [2] we presented a previous approach of the tool explained in this paper. On that occasion, we also presented a matrix as a tool to guide and assess the FDP. The matrix also 
used the Socratic Methodology, but it was organized in a way quite different than that the proposed in this paper. Students found this methodology difficult to follow because questions in the matrix included the three dimensions of sustainability, although they have analyzed these dimensions separately during the degree course. This was the main reason why we decided to develop a new matrix that would be easier for students to understand.

The rest of the paper is organized as follows: Section II presents the related work; in Section III is presented an introduction to the Student's guide for the sustainability analysis; the sustainability analysis is defined in Section IV; Section V and VI detail the questions to be answered by the students in the sustainability analysis, and finally Section VII concludes the paper.

\section{RELATED WORK}

At present, very few experts are against the introduction of sustainability awareness into university studies, specifically, into the engineering curricula. Ciampi and Brito [3] remark that engineering is inserted in the environment of a new global scenario where megaprojects, infrastructure, sustainability, security and multicultural work teams pose challenges that engineers may be not equipped to meet. Although universities are currently producing good engineers, the system for educating future engineers is bound to change. In a special FIE session, Prins et A1. [4] stimulated discussion about the best way to incorporate sustainability into undergraduate engineering education. Notwithstanding, some authors believe that sustainability is a political issue that extends the responsibilities of engineers. According to Miller [5], the perpetual nature of sustainability leads to severe and perhaps unreasonable restrictions on engineering. On the other hand, Diehl et Al. [6] consider the challenges involved in integrating sustainability issues. These authors propose a discussion on the issue of whether sustainability education should be offered separately from or integrated into regular courses.

The Brundtland Commission ${ }^{1}$ in 1987 , and the Sustainable Development Goals of United Nations ${ }^{2}$ in 2015 both identify environmental protection, social equality and economic growth as the pillars on which sustainable development is based. Sustainability awareness is one of the professional skills required by the $\mathrm{ABET}^{3}$ accreditation system introduced into American engineering education in the mid-1990s. ABET introduced a significant change in the criteria required for engineering programs to be accredited. Among these criteria are: a grasp of professional and ethical responsibility and a broad understanding of the impact that engineering solutions have over the global, economic, environmental and social context.

In Europe, the Tuning ${ }^{4}$ project, started in 2000 and led by the University of Deusto, and which is supported by more than

\footnotetext{
1 www.un-documents.net/our-common-future.pdf. Last consult April 2016.

${ }^{2}$ www.un.org/sustainabledevelopment/sustainable-development-goals/. Last consult April 2016.

3 "Accreditation Criteria". Accreditation Board for Engineering and

Technology, Inc. http://www.abet.org. Last consult April 2016.

${ }^{4}$ http://tuning.unideusto.org/tuningal/. Last consult April 2016.
}

one hundred European universities, is focused on the design of a methodology that favours curriculum understanding and standardization among universities. Tuning proposes the acquisition of 31 generic skills. Eight of these skills are directly related to sustainability: Ability to show awareness of equal opportunities and gender issues (6), Ability to act on the basis of ethical reasoning (17), Ability to design and manage projects (22), Ability to act with social responsibility and civic awareness (23), Appreciation of and respect for diversity and multiculturalism (25), Commitment to the conservation of the environment (28), Ability to adapt to and act in new situations (29), and Ability to evaluate and maintain the quality of work produced (30). Other skills proposed therein are also associated with sustainability; for instance: the Ability to plan and manage time (5), Ability to identify, pose and resolve problems (10), Ability to make reasoned decisions (12), Ability to work in a team (14), Ability to take the initiative (20), Ability to design and manage projects (22), Determination and perseverance in the tasks given and responsibilities taken (24), and Ability to motivate people and move toward common goals (31) are regarded as necessary to ensure the economic viability of a project ${ }^{5}$. The first result of this project was a standard to define professional -generic- skills in the context of the European Higher Education Area, which was subsequently extended to Latin America.

Rao et Al. state in [7] that current engineering students will work in a world where resources will be scarcer and global climate change will continue to increase, and this in a context where the population grows steadily and aspires to greater social equity. In short, they will work in a world where sustainability is vital to engineering practice. "However, there is neither a consensus on a set of sustainability concepts on which to base an engineering curriculum nor a standardized mechanism for assessing student learning. Engineering educators lack rigorous assessment tools to judge the success of sustainability education". In other words, once the academic world has reached a consensus on the importance of introducing sustainability into engineering curricula, we have yet to reach an agreement on what to evaluate and how it should be evaluated.

Proposals about how to introduce and assess sustainability in higher education and, specifically, in engineering studies, are many and varied. However, most of them are devoted to how sustainability may be introduced, while only a few address in detail how it can be assessed. For this reason, Rao et $\mathrm{Al}$. [7] point out the lack of rigorous assessment tools to enable engineering teachers to judge the success of sustainability education.

To introduce sustainability in the classroom, Lee et Al. [8] and Pahwa et Al. [9] present proposals that deal only with the environmental aspect of sustainability. Date and Chandrasekharan [10] include the practice of building technological devices in the classroom in order to integrate complex concepts and values such as sustainability. From a different point of view, Pappas et Al. [10] use Bloom's taxonomy of Educational Objectives [11] to develop an instructional methodology for integrating the four

\footnotetext{
${ }^{5}$ Viability is part of the project sustainability, as it is shown in next sections.
} 
sustainability axes (environmental, social, economic and technical) in an engineering design curriculum.

Lopez et Al. [1] are concerned about developing "Sustainability and Social Commitment" skills (SSC) in engineering degree curricula. They propose the provision of general education in SSC to teachers and SSC-related material for each subject. Penzenstadler and Fleischmann [12] present a similar strategy for integrating the concept of sustainability into a degree course scheme across three stages: find a core of interested people by offering a seminar, then broaden the awareness for sustainability by offering a lecture series, and finally establish the topic by offering teach-the-teacher seminars and integration into software engineering lectures.

Kemppainen et Al. [13] explain how they introduce sustainability awareness to first year students at Michigan Technological University. They begin by learning the definition of sustainability and then going on to examine its importance to engineering by means of the following: (i) researching and presenting the sustainability of 20th century engineering achievements; (ii) investigating the ethical issues involved in sustainable technologies; (iii) evaluating sustainability case studies using global Sullivan principles; (iv) calculating the individual electrical energy consumption in their residence hall room and the resultant carbon dioxide produced, thereby proposing methods to reduce their energy consumption; (v) analyzing the sustainability of their semester design project. Students were assessed on sustainability in a mid-term exam and in the final exam of the course.

Northrup [14] introduces innovative lab exercises to improve the learning experience of sophomore electrical engineering students at Western New England College. Projects in the lab are designed to enhance the students' ability to achieve ABET outcomes $\mathrm{C}$ (design for realistic constraints) and I (life-long-learning). In the project and lab reports, students are required to address the aspects of cost, sustainability, manufacturability, environmental impact and safety. Assessment of these items was simplified by the inclusion of separate report sections to address each item.

Desai and Thomassian [15] present the results from an experience in a course undertaken at Georgia Southern University. The basic objective was to bring together students from various educational backgrounds and with hands-on activities such as mini design projects that challenge students to think creatively and make some aspect of any chosen system more sustainable. The course under consideration is part of the core curriculum and is open to students from any university major. A physical product prototype is required for evaluation as part of the final project.

Hasna [16] discusses the difficulties of assessing sustainability: "Unlike technical or financial evaluations, where measures are either empirical or numerical estimates, most sustainability evaluations are measured with intangible and proximal criteria." To evaluate sustainability in capstone engineering designs projects, Hasna proposes the application of a social, economic, ecological, technological and time (SEET) framework. He also proposes a long list of criteria for evaluating sustainability.
Rao et Al. [7] discuss the development of an assessmentoriented knowledge framework. They propose categorizing sustainability in 6 areas: traditional environmental goals, resource protection, design criteria, social/societal goals, business perspectives and ethics/guiding values.

We agree with other authors [17] that the FDP provides the best opportunity for practicing and evaluating professional skills such as sustainability. Indeed, we believe that working on the concept of sustainability throughout different subjects of the curriculum is essential. However, the most suitable place for obtaining a holistic view of sustainability is in the FDP, since it represents the future main task of graduates: the engineering projects on which they are to work.

We follow the methodology described in [18] for monitoring and assessing the FDP at the Barcelona School of Informatics. This methodology is based on a three-milestone approach. During the Initial Milestone, students are trained in a 3-credit course called Project Management, which help them to plan the FDP. The course is intensive and lasts for 1 month, at the conclusion of which students are evaluated on the Initial Milestone. The Follow-up Milestone is conducted at the midpoint of the FDP in order to validate that the project has progressed as expected. The Final Milestone is conducted at the end of the project. Students write a full report of the project and give an oral presentation. Both the report and the presentation are considered as part of the evaluation of the Final Milestone. Each milestone is evaluated by using a set of indicators which reflect the different issues involved in seven professional skills. Sustainability is evaluated by two different milestones, the Initial Milestone and the Final Milestone.

Due to the difficulty for students of introducing and evaluating the sustainability of the FDP, we have developed a guide to help them in this task. This guide can also be used by teachers to assess FDP sustainability, and is described in the following sections.

\section{STUDENT GUIDE: INTRODUCTION}

The projects carried out by engineers are the outcome of applying the knowledge acquired throughout their studies and career development. The last academic step required for a student to earn a degree is to present an FDP, which must be defended with a report and an oral presentation (and the unavoidable slideshow). This document presents a set of recommendations to help students to focus on the sustainability analysis of the FDP. These recommendations may apply subsequently throughout the student's professional life as an engineer.

At the Barcelona School of Informatics, the students go through a pre-project course called Project Management. In this course they learn project management methodologies and receive guidance on how to prepare their project definition report. Once this is completed, the students embark on the project phase, in which they are monitored by the project director. At the end of the FDP, they present a report and give an oral presentation. 


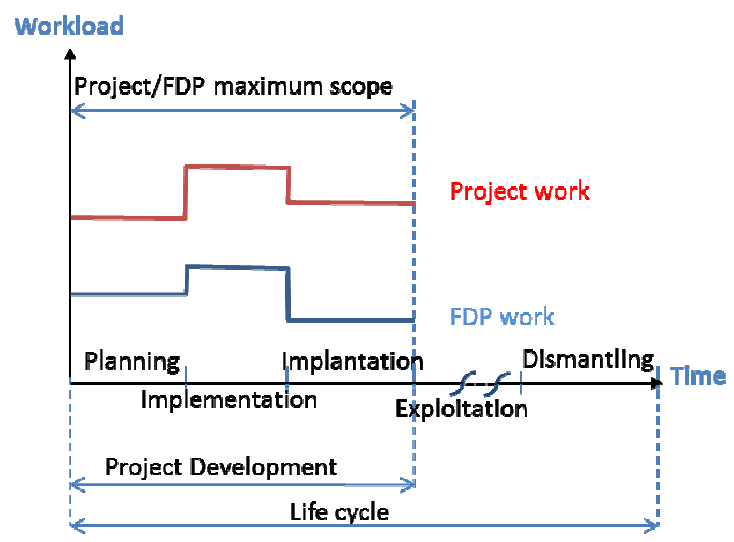

Fig. 1. Life cycle of a project.

The outcome of a project is any product produced or service provided. The first part of the life cycle of a product/service consists of the Project Development (hereafter, PD), comprising the planning, design and implementation as well as the implantation of the project, subsequently ending when the exploitation phase begins. However, an engineering project may end much earlier, since it is determined by its scope (although the scope of many projects is in fact the PD). The same is true for an FDP: its scope can be even smaller than the complete PD due to time constraints imposed because it should finish in one semester.

Figure 1 represents the life cycle of a project. In general, an FDP will require less effort than the average engineering project, because it is only one part of the broader PD. In any case, the PD and the FDP are usually regarded as completed when both are under way. The undertaking outlined in Figure 1 illustrates the differences in workload during the different phases of the project. In general, it will be lower in an FDP than in an engineering project. The amount of work assigned to the planning, implementation and implantation in the figure are given purely as an example and are not indicative of the actual work involved in a project.

\section{STUDENT GUIDE: THE FDP SUSTAINABILITY ANALYSIS}

All FDP reports presented at the Barcelona School of Informatics (FIB) are required to include a chapter entitled "Sustainability Analysis". Given the diverse nature of the FDPs, this report cannot be precisely defined by a simple general outline. It is for that reason that in this document we have drawn up a series of guidelines to assist students in the process of crafting their own analysis.

\section{A. The Sustainability Matrix}

We encourage students to base their sustainability analysis on the application to the FDP Sustainability Matrix presented in Figure 2. This matrix is based on the ideas of "The economy for the common good" by Christian Felber [19]. A detailed explanation of the matrix and an example of its application to a major engineering project, the design with sustainable criteria of the Death Star from Star Wars, can be found in [20].
Analysis of the sustainability of the project is divided into three parts, identified by the columns of the matrix:

- The project development (PD), which includes planning, design and implementation, and implantation of the project.

- The exploitation phase of the project, which begins once it has been implanted and ends when it is dismantled.

- The risks inherent in the project itself throughout its construction and life.

Each of the columns must be analyzed from three perspectives: economic, social and environmental, the three dimensions of sustainability.

When referring to risks we mean those variables that may either determine the success or failure of the project, and which can be identified but not controled. For example, the dependence on a project of one or more persons is a risk that, while acceptable in some projects, may cause failure if these persons leave the organization or become less involved in the project. However, in most cases unforeseen risks cannot be anticipated, because they fall outside the expected life cycle and therefore are not taken into account in the sustainability analysis. One possible risk, for example, would be if a mobile application is designed for online sales and competitors decide to copy the idea with a similar initiative. Nevertheless, it would be surprising if a state law prohibited next week's sales coming through from Internet. Contingencies such as these cannot be anticipated.

The meaning of each of the cells in the matrix is as follows:

- Environmental/Project Development Cell: Represents the energy and resources used during the planning, design, implementation and implantation of the whole project (FDP, in the case of this document) and the impact that this usage will have on the environment. It can be measured, for example, in tons of $\mathrm{CO} 2(\mathrm{tCO} 2)$.

- Environmental/Exploitation Cell: represents the ecological footprint of the project during the exploitation phase.

\begin{tabular}{|c|c|c|c|}
\hline & $\begin{array}{c}\text { Project } \\
\text { Development }\end{array}$ & Exploitation & Risks \\
\hline \multirow[t]{2}{*}{ Environmental } & $\begin{array}{c}\text { Consumption } \\
\text { Design }\end{array}$ & $\begin{array}{c}\text { Ecological } \\
\text { footprint }\end{array}$ & $\begin{array}{c}\text { Environmental } \\
\text { risks }\end{array}$ \\
\hline & $0: 10$ & $0: 20$ & $-20: 0$ \\
\hline \multirow[t]{2}{*}{ Economic } & Project Bill & Viability plan & Economic risks \\
\hline & $0: 10$ & $0: 20$ & $-20: 0$ \\
\hline \multirow[t]{2}{*}{ Social } & $\begin{array}{l}\text { Personal } \\
\text { impact }\end{array}$ & Social impact & Social risks \\
\hline & $0: 10$ & $0: 20$ & $-20: 0$ \\
\hline \multirow{2}{*}{$\begin{array}{c}\text { Sustainability } \\
\text { range }\end{array}$} & $0: 30$ & $0: 60$ & $-60: 0$ \\
\hline & \multicolumn{3}{|c|}{$(-60: 90)$} \\
\hline
\end{tabular}

Fig. 2. FDP Sustainability Matrix. 
- Environmental/Risks Cell: represents the set of eventualities that could cause the project's environmental impact to be more negative than anticipated in the project report.

- Economic/Project Development Cell: represents the consumption of resources (materials and time) incurred during the planning, design, implementation and implantation of the whole project as well as the cost of those resources. It would be the equivalent to the bill that would be charged to a potential customer. A detailed time schedule is required for completion.

- Economic/Exploitation Cell: represents the viability plan of the project. In the case of an FDP, this plan could be drawn up superficially.

- Economic/Risks Cell: represents the set of eventualities that could cause the project to deviate from the estimated costs.

- Social/Project Development Cell: represents the impact the project has had on the people who worked on its development. In the case of the FDP, it concerns the changes and reflections induced in the student by the project.

- Social/Exploitation Cell: represents the impact that the exploitation of the project will have on the collectives affected either directly or indirectly by the project's expected or unexpected outcomes.

- Social/Risks Cell: represents the set of eventualities that could cause the social impact to be harmful or negative.

The FDP is a subset of the PD, as shown in Fig. 3. The student will apply the recommendations contained in this document to the scope of the FDP. However, the FDP scope may be less than the PD, as it may have not reached the implementation phase (for example). Therefore, in this document the general term PD will be used, although the student should implement the recommendations to the work done in the FDP.

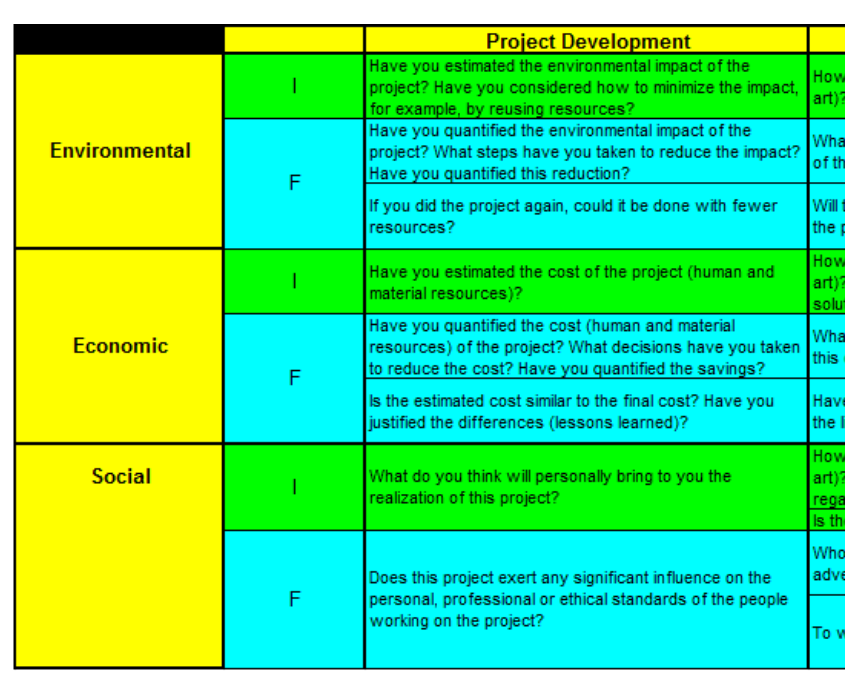

\begin{tabular}{|c|c|c|c|c|}
\hline & & Project Development & Exploitation & Risks \\
\hline \multirow{3}{*}{ Environmental } & 1 & $\begin{array}{l}\text { Have you estimated the environmental impact of the } \\
\text { project? Have you considered how to minimize the impact, } \\
\text { for example, by reusing resources? }\end{array}$ & $\begin{array}{l}\text { How is the problem you want to address currently being solved (state of the } \\
\text { art)? How will your solution environmentally improve current solutions? }\end{array}$ & \\
\hline & \multirow{2}{*}{$\mathrm{F}$} & $\begin{array}{l}\text { Have you quantified the environmental impact of the } \\
\text { project? What steps have you taken to reduce the impact? } \\
\text { Have you quantified this reduction? }\end{array}$ & $\begin{array}{l}\text { What resources do you estimate will be used during the exploitation phase } \\
\text { of the project? What will be the environmental impact of these resources? }\end{array}$ & \multirow{2}{*}{$\begin{array}{l}\text { Could any scenarios arise that might increase the footprint } \\
\text { of the project? }\end{array}$} \\
\hline & & $\begin{array}{l}\text { If you did the project again, could it be done with fewer } \\
\text { resources? }\end{array}$ & $\begin{array}{l}\text { Will the project reduce the use of other resources? ¿Overall, will the use of } \\
\text { the project improve or worsen the ecological footprint? }\end{array}$ & \\
\hline \multirow{3}{*}{ Economic } & 1 & $\begin{array}{l}\text { Have you estimated the cost of the project (human and } \\
\text { material resources)? }\end{array}$ & $\begin{array}{l}\text { How is the problem you want to address currently being solved (state of the } \\
\text { art)? What could economically improve your solution as regards current } \\
\text { solutions? }\end{array}$ & \\
\hline & \multirow{2}{*}{$\mathrm{F}$} & $\begin{array}{l}\text { Have you quantified the cost (human and material } \\
\text { resources) of the project? What decisions have you taken } \\
\text { to reduce the cost? Have you quantified the savings? }\end{array}$ & $\begin{array}{l}\text { What is the estimated cost of the project over its exploitation phase? Could } \\
\text { this cost be reduced to make the project more feasible? }\end{array}$ & \multirow{2}{*}{$\begin{array}{l}\text { Could any scenarios arise that may jeopardize the viability } \\
\text { of the project? }\end{array}$} \\
\hline & & $\begin{array}{l}\text { Is the estimated cost similar to the final cost? Have you } \\
\text { justified the differences (lessons learned)? }\end{array}$ & $\begin{array}{l}\text { Have you taken into account the cost of adjustments / updates / repairs over } \\
\text { the lifetime of the project? }\end{array}$ & \\
\hline \multirow[t]{3}{*}{ Social } & 1 & $\begin{array}{l}\text { What do you think will personally bring to you the } \\
\text { realization of this project? }\end{array}$ & $\begin{array}{l}\text { How is the problem you want to address currently being solved (state of the } \\
\text { art)? What could socially improve (e.g., quality of life) your solution as } \\
\text { regards those previously adopted? } \\
\text { Is there a real need for the project? }\end{array}$ & \\
\hline & \multirow{2}{*}{$\mathrm{F}$} & \multirow{2}{*}{$\begin{array}{l}\text { Does this project exert any significant influence on the } \\
\text { personal, professional or ethical standards of the people } \\
\text { working on the project? }\end{array}$} & $\begin{array}{l}\text { Who benefits from the use of the project? is there any group that may be } \\
\text { adversely affected by the project? If so, to what extent? }\end{array}$ & $\begin{array}{l}\text { Could any scenarios arise to make the project detrimental } \\
\text { to any particular segment of the population? }\end{array}$ \\
\hline & & & To what extent does the project solve the problem initially raised? & $\begin{array}{l}\text { Could the project create any kind of dependency that } \\
\text { might leave users in a weak position? }\end{array}$ \\
\hline
\end{tabular}

Fig. 4. Questions in the FDP Sustainability Matrix.

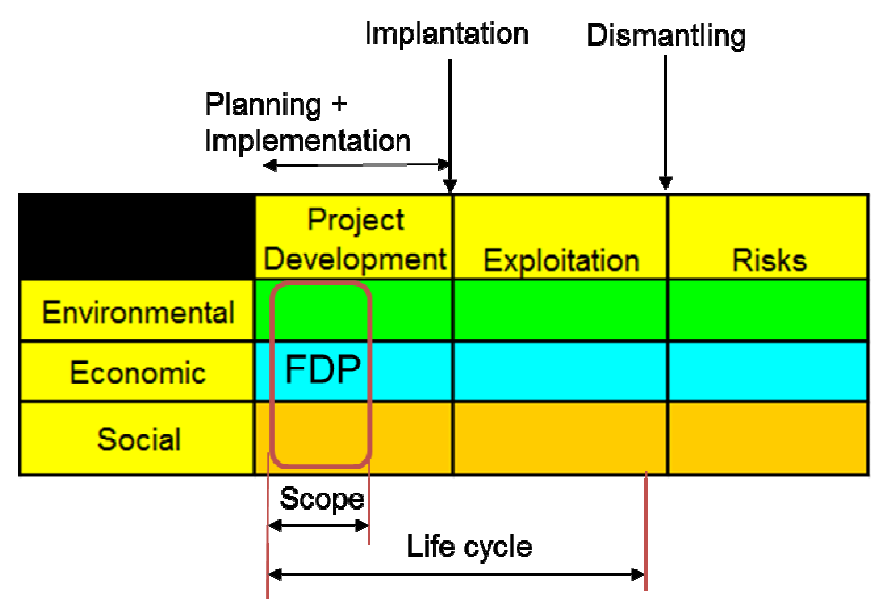

Fig. 3. FDP scope in the Sustainability Matrix.

\section{B. Questions that students should take into account}

According to the Socratic Methodology [21], the guide to preparing the sustainability analysis takes the form of questions that students are required to answer in the corresponding chapter of the report. Fig. 4 provides examples of such questions. The questions are not intended to be exhaustive, so the student must consider which ones are relevant for the FDP. Therefore, we provide below a brief description and a set of questions for analyzing each cell in the Sustainability Matrix.

The goal is not to create a report out of a list of questions and their answers, but rather to write a descriptive report based on the analysis arising from the questions, including all relevant information derived from the questions.

Questions in the row labelled "I" (Initial Milestone), which are highlighted in green, are questions that the student must consider during the Project Management course. Those in the row labelled "F" (Final Milestone) must be justified in the sustainability analysis included in the final project report. As shown in Fig. 4, the issue of risk analysis should not be raised during the Project Management course, but should be included in the final project report. 


\section{Weighting matrix}

As shown in Fig. 2, each of the matrix cells has a weight assigned according to its influence on the sustainability of the FDP. During the project's development and exploitation, assessments can only be positive, while the risks, if any, have a negative assessment, as shown in Fig. 2.

The student will analyze the sustainability of FDP by taking into account the weighting of each of the matrix cells by using the following evaluation criteria:

- A score from 0 to 10 points for each of the cells corresponding to the $\mathrm{PD}$, with 10 being a really sustainable FDP for the criteria considered in that cell, and 0 a non-sustainable FDP.

- A Score from 0 to 20 point for each of the cells corresponding to the exploitation phase, with 20 being the most sustainable score and 0 a non-sustainable FDP. The weighting is twice that in the project development because the impact on the sustainability of the project's exploitation phase is, in general, much larger than that produced during its development.

- A score from -20 to 0 for the cells corresponding to the risks, with 0 meaning that no risks are detected for the cell in question, while -20 means that the student has identified potentially dangerous (and probable) risks. We propose a negative weight on this part, in accordance with Felber's model of the Common Good matrix [19].

The final sum will provide an idea of the level of sustainability of the project, which may range from -60 to 90. The higher the score, the more sustainable is the project considered to be.

\section{Evaluation criteria and sustainability self-assessment analysis}

The sustainability analysis included in the project report must include the values that students assign to each cell in the matrix (self-assessment). This valuation should be accompanied by data where possible. In cases where a particular cell or question has no applicability to the FDP, the reason for such inapplicability should be explained and the corresponding cell will be set to zero. If the inapplicability is duly justified, it will have no effect on the students' grade for the project sustainability. Teachers assessing the projects are instructed to consider the explanations for each value in the matrix, not the value itself. The result of the sum of the values in the matrix may yield a very low score, indicating that the student does not consider the project to be sustainable. However, students who conduct a good analysis may obtain a good score for the sustainability skill.

\section{E. Structure and organization of the sustainability analysis}

As already mentioned above, the project report should contain a chapter entitled "Sustainability Analysis". This report may be drawn up by analyzing the matrix by rows or columns. A short analysis of the cases in which either of the two models is more appropriate is provided below.
1) Analysis by rows

If we wish to focus on each of the sustainability dimensions of the project, it is more suitable to perform the analysis by rows. In this case, the sustainability analysis is divided into three sections, called respectively "Economic Impact study", "Environmental Impact study" and "Social Impact study.". In general, engineering projects should be carried out according to this type of analysis by rows.

\section{2) Analysis by columns}

A second way to conduct the sustainability analysis is to perform the analysis by columns. In this case, the sustainability analysis should be divided into three sections, called respectively "Project Development," "Exploitation phase" and "Risks". It makes sense to perform this type of analysis in those FDPs whose scope does not include the implantation phase, or when the sustainability of the exploitation phase cannot be conveniently analyzed because the analysis is more focused on the work done during the FDP. In this case, analysis of the exploitation phase and the risks involved will not be so exhaustive.

\section{STUDENT GUIDE: QUESTIONS TO BE RAISED AND JUSTIFIED IN THE INITIAL MILESTONE}

This section is organized according to the model of analysis by rows, although there is nothing to prevent students from organizing the sustainability analysis in accordance with analysis by columns if they believe that it is more suitable for the FDP.

In the Project Management course, students should only raise issues concerning the Initial Milestone; in other words, those corresponding to the row labelled "I" in each dimension. A partial assessment is therefore given to the matrix.

\section{A. Environmental Impact study}

The following questions refer to the environmental impact of the project. In the Initial Milestone, the student should estimate the environmental resources consumed during the project development. Specifically, students should answer the following questions from the two rows of the matrix labelled "consumption design" and "ecological footprint":

\section{1) Consumption design}

- Have you estimated the environmental impact of the project? Have you considered how to minimize the impact, for example, by reusing resources?

\section{2) Ecological footprint}

- How is the problem you want to address currently being solved (state of the art)?

- How will your solution environmentally improve current solutions?

\section{B. Economical Impact study}

This section addresses the issues that students should take into account regarding project viability. A deep analysis on viability such as return on investment or financing is not required. Nevertheless, this type of analysis is necessary for a master or engineering project. 
The following questions refer only to the economic cost of the project development. In the Initial Milestone, students are required to arrive at an estimate of the project cost (including a detailed plan). During this Initial Milestone, students must answer the following questions, which correspond to the two matrix rows labelled "project bill" and "viability plan".

1) Project bill

- Have you estimated the cost of the project (human and material resources)? Detailed planning and an estimated cost for the project must be presented.

2) Viability plan

- How is the problem you want to address currently being solved (state of the art)? Economic calculations must be presented.

- What could economically improve your solution as regards current solutions?

\section{Social Impact study}

In this section we address the issues that students should take into account concerning the social impact of the project. The social implications for the collective involved in the project should be considered, as well as those for other collectives. If a recycling system is set up, for instance, then this constitutes a social improvement, although the daily life of users may become a little more complicated because a change in habits is required.

The collectives involved in the project include: (i) owners/project managers, (ii) consumer/direct users and (iii) third/indirect/passive people. For example, in current apps that enable sharing the use of a vehicle, the owner/manager keeps the app, the direct users are the driver and the passenger, and those indirectly involved could be taxi drivers, who are an example of a collective that may be affected by a decrease in business.

Students must answer the following questions for the rows labelled "personal impact" and "social impact":

\section{1) Personal Impact}

The following questions refer to the influence on students of the design and implementation of the project; i.e., whether their lives have changed or not; whether they have become aware or not of situations they previously ignored.

- What do you think will personally bring to you the realization of this project?

2) Social Impact

The following questions are designed to stimulate thought about the implications that the project may have on society.

- How is the problem you want to address currently being solved (state of the art)? In other words, you must identify the group of those affected with the problem/need that you intend to deal with.

- What could socially improve (e.g., quality of life) your solution as regards those previously adopted? Will your project improve the quality of life of those affected (users, non-users, investors, employees, etc.)? How?

- Is there a real need for the project? In other words, is the goal of your project to improve the lives of those affected (users, non-users, investors, employees, suppliers, etc.) or to fill the file?

\section{STUDENT GUIDE: QUESTIONS TO BE RAISED AND JUSTIFIED IN THE FINAL MILESTONE}

This section is also organized according to the model of analysis by rows. However, there is nothing to prevent students from organizing the sustainability analysis according to analysis by columns if this is more suitable for the FDP.

\section{A. Environmental Impact study}

The following questions refer to the environmental impact of project development. In the Initial Milestone, students only estimate the environmental resources required for the project development, whereas in the Final Milestone calculations of environmental consumption must be also submitted. Estimation and calculation should be included and compared in the sustainability analysis.

Specifically, students must answer the following questions for the two rows of the matrix labelled "consumption design" and "ecological footprint":

\section{1) Consumption design}

- Have you quantified the environmental impact of the project? What steps have you taken to reduce the impact? Have you quantified this reduction? To answer these questions, a numerical impact assessment (consumption in watts, tons of $\mathrm{CO} 2$ generated by the consumption depending on the energy source used, etc.) must be presented. Multiple ecological calculators to help you make these calculations can be found on the Internet.

- If you did the project again, could it be done with fewer resources?

\section{2) Ecological footprint}

- What resources do you estimate will be used during the exploitation phase of the project? What will be the environmental impact of these resources? An ecocalculator like the one suggested for the previous question can be used for your answer.

- Will the project reduce the use of other resources? $¿$ Overall, will the use of the project improve or worsen the ecological footprint? The ecological calculator will again help you to answer this question.

\section{3) Environmental risks}

- Could any scenarios arise that might increase the footprint of the project? Explain possible scenarios (which cannot be addressed due to lack of time, such as resources or unsuitability) that may lead to an increase in the ecological footprint. 


\section{B. Economic Impact study.}

This section concerns the questions that students should consider with regard to the economic viability of the project. It is not necessary for students to carry out an advanced study of viability with investment return and other questions. These aspects should be completed by a master student or an engineer in a real engineering project.

The following questions refer to the economic cost of the project development. In the Initial Milestone, students carry out an estimation of the project cost (including detailed planning), whereas in the Final Milestone they should also provide an economic calculation of the project invoice and analyze any changes to the initial planning. Students must answer the following questions regarding the matrix rows labelled "project bill", "viability plan" and "economic risks".

\section{1) Project Bill}

- Have you quantified the cost (human and material resources) of the project? What decisions have you taken to reduce the cost? Have you quantified the savings?

- Is the estimated cost similar to the final cost? Have you justified the differences (lessons learned)?

2) Viability plan

- What is the estimated cost of the project over its exploitation phase? Could this cost be reduced to make the project more feasible?

- Have you taken into account the cost of adjustments / updates / repairs over the lifetime of the project?

\section{3) Economic Risks}

- Could any scenarios arise that may jeopardize the viability of the project? Explain probable possible scenarios (not necessarily significant) that you cannot analyze due to lack of resources, time or ability, and which may jeopardize the economic viability of the project.

\section{Social Impact study}

This section deals with the questions that students must answer regarding the social impact of the FDP. The social implications for collectives directly related to the project and for other collectives should be considered. For example, if a recycling system is created, this constitutes a social improvement, but the daily life of the users may thereby become more complicated since changes in habits are required.

The collectives involved in the project are: (i) owners/project managers, (ii) consumer/direct users and (iii) third/indirect/passive people. For example, some side effects arising from the use of current apps for car-sharing refered to in the previous section may arise, such as the (positive) impact on traffic and environmental pollution. These effects should be considered in the corresponding matrix cells.

Students must answer the following questions related to the three matrix rows labelled "personal impact", "social impact" and "social risks".

\section{1) Personal impact}

The following questions refer to how the achievement of the FDP has directly affected the personal life of the students themselves. In the Final Milestone, students should reflect on the following:

- Does this project exert any significant influence on the personal, professional or ethical standards of the people working on the project?

2) Social Impact

The following questions are design to stimulate student about the implications that the project may have on society:

- Who benefits from the use of the project? Is there any group that may be adversely affected by the project? If so, to what extent?

- To what extent does the project solve the problem initially raised? Is the solution just a possible solution, or it is the definitive solution? How deeply and passionately are you committed to your project?

3) Social Risks

- Could any scenarios arise to make the project detrimental to any particular segment of the population?

- Could the project create any kind of dependency that might leave users in a weak position? Describe probable scenarios that you are unable to analyze due to lack of resources, time or ability, and which may jeopardize the users, investors, workers, providers, etc. involved in the project.

\section{CONCLUSIONS}

Humankind must learn to share the planet and its limited resources. This is not an issue of being a committed person, but rather of incorporating ideas about sustainability into all our daily activities. Engineers can contribute to a more sustainable world by including sustainability parameters in their professional projects. Integrating these issues as part of their work is a habit that must be acquired during their university training, when future engineers are learning the very basics of their work. One of the milestones of engineers' education is the development of projects, especially during their degree/master thesis. In this work, we have presented a methodology for the introduction and assessment of sustainability as part of these projects, and we have applied the methodology to a degree in computing.

This methodology consists of a simple design and is aimed at helping students to think about the relationship between sustainability and engineering. In a complex, unorganized or unreal method, students will focus on writing a sustainability analysis just to ticket the task as "done", but without any deep reflection (and thus, in-depth learning) about sustainability.

Our future work will consist in evaluating the quality of the sustainability analysis of our students in the coming years, and, if possible, the analysis of the sustainability inherent in their real-life projects. This should constitute a real test of the deep understanding of sustainability acquired by our students. 


\section{References}

[1] D. López; F. Sánchez; J. Garcia; M. Alier; J. Piguillem and M. Velasco. "Introducing Sustainability and Social Commitment skills in an engineering degree". 41th IEEE Frontiers in Education Conference (FIE 2011). IEEE Conference Publications. pp. S2C-1 - S2C-6. Rapid City, SD. Oct. 2011.

[2] D. López; F. Sánchez; E. Vidal; J. Pegueroles; M. Alier; J. Cabré; J. Garcia and H. Garcia. "A methodology to introduce sustainability into the final year project to foster sustainable engineering projects". 44th IEEE Frontiers in Education Conference (FIE 2014), IEEE Conference Publications. pp. 1-7. Madrid, Oct.2014.

[3] M. M. Ciampi and C. d. R. Brito "Professional engineering education program". 39th IEEE Frontiers in Education Conference (FIE 2009). San Antonio,TX. pp. 1,-3. 2009.

[4] R. Prins, R. Kander, T. Moore, E. Pappas and O. Pierrakos. Special Session - Engineering for a sustainable world: "How do we incorporate sustainability in undergraduate engineering education?". 38th IEEE Frontiers in Education Conference (FIE 2008). Saratoga Springs, NY. pp. S2J-1 - S2J-2. Oct. 2008.

[5] Miller, Glen. "Exploring Engineering and Sustainability: Concepts, Practices, Politics, and Consequences". Engineering Studies. Vol. 6, Iss. 1, 2014.

[6] J. C. Diehl; C. Boks and S. Silvester. "The Evolution of Design for Sustainability Courses". Fourth International Symposium on Eco Design. Environmentally Conscious Design and Inverse Manufacturing. IEEE Conference Publications. pp. 78-85. Tokyo, Dec.2005.

[7] R. Rao, A. L. Pawley, S. R. Hoffmann, M. W. Ohland and M. E. Cardella. Work in progress — "Development of a framework to Assess Sustainability Knowledge (ASK) in engineering undergraduate students". 40th IEEE Frontiers in Education Conference (FIE 2010).Wshington, DC. pp. F1J-1 - F1J-3. Oct. 2010.

[8] J. Lee; N. Okamoto; R. Chung and T. Anagnos. "Introducing sustainability concepts in lower division engineering core courses". 41th ASEE/IEEE Frontiers in Education Conference. (FIE 2011). IEEE Conference Publications. pp. F4J-1 - F4J-6. Rapid City, SD. Oct. 2011.

[9] A. Pahwa; W. B. Kuhn; R. D. Miller; A. Rys; C. Eldridge; S. Geier; J. Schuler; M. Morley; I. Sobering and J. Stacks. "Activities to infuse sustainability and renewable energy concepts in electrical and computer engineering". 41th ASEE/IEEE Frontiers in Education Conference (FIE 2011). IEEE Conference Publications. pp. F4J-1 - F4J-6. Rapid City, SD. Oct. 2011.

[10] E. Pappas; O. Pierrakos and R. Nagel. "Integrating developmental instruction in four sustainability contexts into an undergraduate engineering design curriculum: Level three". 42th IEEE Frontiers in Education Conference (FIE 2012). IEEE Conference Publications. pp. 16. Seattle, WA. Oct. 2012.

[11] B.S Bloom, M.D Engelhart, E.J Furst, W.H Hill and D.R. Krathwohl. "Taxonomy of Educational Objectives: Handbook I, The Cognitive Domain". New York: David McKay. 1956.

[12] B. Penzenstadler and A. Fleischmann. "Teach sustainability in software engineering?". 24th IEEE-CS Conference on Software Engineering Education and Training (CSEE\&T), IEEE Conference Publications.pp.454-458. Honolulu, HI, May 2011.

[13] A. J. Kemppainen; N. L. Veurink and G. L. Hein." Sustainability in a common first year engineering program". 37th IEEE Frontiers In Education Conference - Global Engineering: Knowledge Without Borders, Opportunities Without Passports. (FIE 2007). pp. S2J-1 - S2J6. Milwaukee, WI, Oct. 2007.

[14] S. G. Northrup. "Innovative lab experiences for introductory electrical engineering students". 39th IEEE Frontiers in Education Conference. (FIE 2009). IEEE Conference Publications. pp. 1-6. San Antonio, TX. Oct. 2009.

[15] A. Desai and J. C. Thomassian. Work in Progress - "Incorporating 'sustainability' into the core curriculum through the development of an introductory course". 39th IEEE Frontiers in Education Conference (FIE 2009). IEEE Conference Publications. pp. 1-2. San Antonio, TX. Oct.2009.

[16] A. M. Hasna. "Embedding sustainability in capstone engineering design projects". Published in Education Engineering (EDUCON), IEEE. pp. 1601-1610. Madrid, April 2010.

[17] J.L. Sánchez, C. S. González, and S. Alayon. "Evaluation of transversal competences in the final year project in engineering." Proceedings of the 22nd EAEEIE Annual Conference. (EAEEIE), June, 2011.

[18] F. Sánchez, J. Climent, J. Corbalán, P. Fonseca i Casas, J. Garcia, J. R. Herrero, X. Llinàs, H. Rodríguez, M.-R. Sancho, M. Alier, J. Cabré, and D. López. "Evaluation and assessment of professional skills in the Final Year Project". 44th IEEE Frontiers in Education Conference (FIE 2014). Madrid, Spain, October 23-25, 2014, pp. 2352-2359.

[19] C. Felber. Die Gemeinwohl-Ökonomie - Das Wirtschaftsmodell der Zukunft. 2010.

[20] F. Sánchez, J. Garcia, D. López, M. Alier, J. Cabré, H. García, E. Vidal, and C. Martín. “Es sostenible la Estrella de la Muerte?” ReVisión, Vol 8, Num. 3. pp. 81-103, september 2015.

[21] F. Sánchez, J. Garcia, D. López, M. Alier, J. Cabré, H. García and E. Vidal. "El método socrático como guía del Trabajo de Fin de Grado". ReVisión, ISSN 1989-1199, Vol. 8, Num. 1. pp. 53-61, January 2015. 